\title{
Web Interface for Education of Mentally Disabled Persons for Work in Horticulture
}

\author{
P. Benda, M. Šmejkalová \\ Faculty of Economics and Management, Czech University of Life Sciences Prague, \\ Czech Republic
}

\begin{abstract}
Anotace
Předkládaný článek se zabývá tvorbou vhodného webového rozhraní pro vzdělávání osob s mentálním postižením pro práci v zahradnictví. Výzkum je založen na testování několika forem webové navigace skupinou mentálně postižených. Testování probíhalo po dobu sedmi týdnů v modelovém kurzu, který seznamoval účastníky s pracovními činnostmi v zahradnictví. Dílčím výzkumem bylo také identifikováno vhodné zařízení pro práci s webovou podobou modelového kurzu. Formulované výsledky byly na modelový kurz zpětně aplikovány a využity pro účely reálné podpory vzdělávání mentálně postižených pro práci v zahradnictví.
\end{abstract}

\section{Klíčová slova}

Př́istupnost, webové rozhraní, mentální postižení, zahradnictví.

\begin{abstract}
This paper deals with the development of a suitable web interface for the education of persons with mental disabilities to work in horticulture. The research is based on the testing of several forms of web navigation by the group of mentally disabled persons. Testing was performed for seven weeks in a model course which acquainted the participants with working activities in horticulture. A partial research has also identified a suitable device and the form of control the web part of model course. Formulated results were retroactively applied to the model course and utilized for the purpose of a real support for education of mentally disabled persons for work in horticulture.
\end{abstract}

\section{Key words}

Accessibility, web interface, mental disability, horticulture.

\section{Introduction}

Integration in employment is perceived as a self-fulfillment of a person, which has a positive effect on self confidence. Training pathways and subsequent employment is a very important and significant milestone in the life of every human being. For the success in simple work activities in sheltered workshops or other customized workplaces people with mental disabilities need to get a number of usable skills and habits in the field of labor education. Everything what these people learn, increase their self-sufficiency, self-reliance and facilitate their surroundings of mutual coexistence. The problem of mentally disabled persons, unlike some of their unaffected peers, is excessive amount of free time that they cannot used effectively. The skills which they gather while working in the workshop, classroom, school, kitchen or on land, will help them alleviate this problem or remove it completely (Švarcová, 2006).

Entry to the open labor market is one of the most important expressions of the social emancipation of people with mental disabilities and also the culmination or the measure of success of previous educational work (Valenta, Müller, 2003).

Creating and implementing support programs for people with mental disabilities is beneficial also in terms of economy. Long-term care is more expensive than supported independence and meaningful work. Even low paid employment or part-time job gives a person with mental disability status of the adult who contributes to the society and this employment also efficiently stimulates and maintains its skills and habits 
(Bartoňová, 2005; Černá, 2009).

People at medium and heavier level of mental disability are realized in the work under supervision - in sheltered workplaces. Other possibility is supported employment. The basic objective is to prepare people with severe disabilities for the performance of less demanding professions. These jobs are characterized by their monotony, and therefore are not sought. These include working as a kitchen helper or doing odd jobs in horticulture, etc. (Pipeková, 2010).

Tas and Tatnall (2010) reported that a significant number of people with mental handicap, learning difficulties, concentration disorder, or other special needs require help and support for their education. Mesiti at al. (2011) adds that the use of ICT and also Internet plays important role in the shaping of knowledge and skills of these people.

Assistive Technology used by mentally disabled persons

The term Assistive Technology (assistance aids) means tools that help to improve physical, sensory or mental functions of people who have these functions reduced for different reasons. Assistive Technology serves people with disabilities as a tool how to deal with their disability, and also help to ensure that those persons may live as well as a healthy population (Keblová, 2006).

Persons with mental disabilities benefit from the assistive technologies in particular to facilitate communication. These devices include:

- Communication tables;

- Large-scale buttons with voice output;

- Tabular communicators.

Besides the buttons and tabular communicators there could be used a special kind of software which is controlled mainly by the touch screen (Kantor, 2012).

The above mentioned findings show that the inclusion of people with mental retardation in the working collective is vital. Mentally disabled persons people with disabilities can realize themselves especially in simple and monotonous work activities. Therefore horticulture is one of the alternatives where they can succeed.

\section{Materials and methods}

Research for development of the web interface for education of mentally disabled persons for work in horticulture was regularly attended by eight participants. Research participants were people with varying levels of mental disability. In all cases, these people permanently live in nursing homes or centers for persons with disabilities, they are not currently employed anywhere and within therapeutic activities they work in sheltered workshops, etc. (Table1).

Down syndrome, also known as Down's disease (morbus Down) is the most common form of mental retardation. People with this syndrome constitute about $10 \%$ of the population of all persons with mental disabilities. Due to the fact that the disorder is widespread and its diagnosis is relatively easy, its symptoms are well known to all professionals working with people with mental retardation. (Švarcová, 2006).

Perinatal encephalopathy, also called cerebral palsy is the name for a whole group of nerve disorders, either congenital or acquired early. Perinatal encephalopathy is the cause of various handicaps at a later age children - motor disorders,

\begin{tabular}{|l|l|l|l|c|}
\hline & Age & $\begin{array}{c}\text { Level of mental retardation } \\
\text { (oligophrenia) }\end{array}$ & \multicolumn{1}{|c|}{ Kind of disorder } & \multicolumn{1}{|c|}{ Associated disability } \\
\hline participant A & 60 & mild & Perinatal encephalopathy & moderate visual impairment \\
\hline participant B & 47 & moderate & Perinatal encephalopathy & - \\
\hline participant C & 48 & moderate & Down Syndrome & - \\
\hline participant D & 52 & mild & Down Syndrome & - \\
\hline participant E & 62 & mild & Perinatal encephalopathy & - \\
\hline participant F & 53 & moderate & Down Syndrome & - \\
\hline participant G & 37 & moderate to severe & Perinatal encephalopathy & $\begin{array}{l}\text { lower extremity motor } \\
\text { function }\end{array}$ \\
\hline participant H & 49 & severe to profound & Perinatal encephalopathy & motor disorder \\
\hline
\end{tabular}

Source: authors“ own research

Table 1: List of research participants. 
epilepsy, impaired intellectual functioning, sense organ disorders, character defects (Švarcová, 2006).

\section{Education of persons with mental disabilities}

Švarcová (2006) states that one of the most commonly used methods of education for children and adults with severe mental disability is so called Social reading. It is usually understood as cognition, interpretation and appropriate response to visual signs and symbols, pictograms, words and groups of words that frequently appear in the environment or in a broader context. To direct learning in a real situation should precede, and also follow after, the learning of these symbols in a controlled environment, eg. in the classroom or at home. Both stages should be accompanied by, using text, pictures or pictograms.

As examples of of this kind of teaching Švarcová (2006) presents a deep-seated and in society widely used kind of pictograms, which are traffic signs and traffic symbols. For their adoption it is necessary to acquaint students with symbols not only in class, but they must also learn the real environment where are those symbols are being used. Otherwise, people can better understand the importance of symbols in a real situation only after their experiencing in the preparation.

Pictograms are nonverbal information, perceivable formations created by drawing, writing, printing or other procedures. Commonly used in public places, buildings, for instructions and warnings. Their aim is to enable people quick orientation wherever the text messages might be an obstacle to understanding, eg. in transport or in hospitals. Each pictogram represents and depicts a factual significance (Gerlichová cited Kantor, 2012).

Špinar (2004) complements that for users with learning or concentration disabilities is a visual content in the form of eg. images or pictograms very important. These objects are able to focus their attention and illustrate the importance of content much better than dozens of lines of text. For this reason it is appropriate to use illustrative images, pictograms, visual bullets, photos, etc. However, to comply with the rules for visually impaired persons, it is necessary to describe each image carrying importance information by html "alt" atribute.

Existing experience confirms that this form of teaching and presentation of materials can actually lead to the improvement in education of people with mental disability and their better inclusion in the society in general and in particular in the field of horticulture (Benda, 2011).

From the above-described recommendations result a requirement for practicality and simplicity in the development of a web interface and also the web content. All textual information must be supplemented by visual content and in particular for Web interface and navigation. Across the interface it is appropriate to define a clear system of pictures and pictograms, accompanied by their clear text identification or label, which will be held throughout all the Web.

\section{Results and discussion}

On the basis of the acquired information there has been web interface for a model course prepared. This course substantively aims to prepare mentally disabled workers for work in horticulture.

Within the model horticultural course there was introduced unequivocal system of pictograms factually associated with individual horticultural activities. This system is not used only in the model course posted on the Web, but it is also referred to places associated with individual horticultural actions on the fields in the real garden.

On the principle of information visualization, and also because of the frequent repetition of the operations, study materials are created in the form of video-demonstrations. These demonstrations are further modified by post-production. Part of the postproduction of video materials describing the various horticulture activities is also enrichment of selected set of pictograms. In terms of materiality and simplicity there were illustrative pictograms selected in form of black and white images.

For a period of seven weeks of practical and theoretical training, research participants were gradually introduced to various videodemonstrations and also they were familiar with used pictograms in terrain. To verify the accuracy of assumptions, research participants were gradually invited to a web page to press correct navigation pictogram to launch the right movie describing the selected activity. Within four testing sessions there were presented four different websites with different forms of simple navigation:

- text horizontal navigation;

- text vertical navigation;

- picture navigation using applied pictograms;

- $\quad$ picture navigation using applied pictograms and short textual description. 
Research participants were measured by time required to start the specified video-demonstration by pressing the navigation element by a finger on the capacitive touch screen device Shuttle PC. This device has been identified as the most suitable based on the associated research, which is mentioned bellow.

Testing of appropriate device for controlling the web page

During the first session with the participants it has been found that the use of a standard keyboard and mouse is unsuitable for them. For this reason we created a simple web page with two images that participants had to point and click.

Research participants tested desktop PC with the controls in the form of a standard keyboard and mouse as the first. Despite the relatively large size of presented images, mouse control was found to be unsuitable. Just a few participants were able to click on the desired image and the time required for navigation was unreasonably long.

To operate a website, to click on a desired image, using only the keyboard it was necessary to add of the attribute "accesskey" to the web source code. This attribute allows control by pressing ALT or CTRL + key associated with the attribute value. Description of the images has been extended by a number that represented it for a navigation.

The necessity of pressing two keys at once and remembering or re-tracing the required number again led to a disproportionate load and stress of participants. This form of navigation had to be described as substandard. Significant improvements in accuracy and speed of control has not been detected using a special keyboard "BigKeys" and very large trackball. For most participants, these were completely new devices and for the most of participants it would have required a long period of training to manage them.

Currently smart devices with a touch screen are very popular. Based on data of the StatCounter (2015) mobile devices with touch screen (phones and tablets) form more than $38 \%$ of platforms using Internet.

The latest research data about the use of this kind of communication technologies by agricultural enterprises in the Czech Republic (carried out by the Department of Information Technologies, 1 August, 2014 Faculty of Economics and Management, Czech University of Life Sciences Prague) show that $43 \%$ of respondents use smart mobile devices for various purposes. Even though only a part of these users utilize their devices for the access to the Web statistics shows an incessant increase in this respect, too (Stočes et al., 2015).

Assuming the possibility of using mobile devices to browse the created web and even the model course also in the terrain, there has been gradually tested three different devices with touch screen:

- Tablet ASUS (resistive touch screen);

- $\quad$ iPad2 (capacitive touch screen);

- PC Shuttle X 5020XA Plus (capacitive touch screen).

Using a device with a touch screen has proved to be very suitable. Navigation of web become more intuitive for participants. Using the touch pen (stylus) in case of resistive ASUS tablet touch screen has once again led to delays in navigation. On the contrary pressing it by a finger were performed by participants quite naturally and with a high accuracy. In addition, this form of navigation could be used by all participants in the research.

An effective control of devices by participants reached especially if the device was placed on solid surface and they have not to hold it with the other hand. Possible need of so called multi-point or multi-touch control of device proved to be also inconvenient. Once the content of the web page was not been customized to the resolution of a device display and participants were forced to use both vertical and horizontal scroll bar, this situation caused delays in navigation and loss of concentration again. When there was an $\mathrm{iPad} 2$ used in this case, it was necessary to use multi-touch to zoom the web page. This feature could effectively handle none of the participants.

From the made examinations implies that the website must be able to adapt the resolution of the device used by the user. If not this state makes difficulties to navigate and use the web page by all users. Lestari et al. (2014) notices, that this condition may cause hidden critical links, hidden components, as well some hidden important information that should have been presented to users without needing them to do horizontal scrolling thus decreasing the deliverable effect of certain values from website. Moreover, it can decrease website experience for website users at all.

The appropriate solution is to use responsive 
design. As Marcotte (2011) stated, under this designation it is understood the design of websites that automatically adjusts the width of the display device. It is a modern approach to creating websites and also a compromise between the fixed design, so the design with a fixed width content, and a fluid design with variable width content.

After the application of responsive design principles and the location of the device on a solid surface, participants were able to click on the images pretty fast and virtually flawlessly pass. Participants selected PS Schuttle device as the most applicable especially for the optimal dimensions of a diagonal size of the screen and robustness.

According to the conducted research and in comparison with scientific publications (van de Ven and de Haan, 2003; Lee and Forshay cited Denaes, 2012; Huguenin, 2000) can be mentioned touch screen as the most suitable technology for controlling web page by persons with mental disabilities. Lee and Forshay (in Denaes, 2012) specifically states: "Touch screen computers seem to be the best option for this population because their movements do not need to be as precise as with the computer mouse. Besides, the touch screen is also known to improve the motivation and the attention span of the participants."

\section{Selection of appropriate web interface}

As already mentioned, four kinds of web interface was therefore tested by research participants using the PC Shuttle device with touch screen on a web page created by the principles of responsive design. Participants were measured by time required to start the specified video-demonstration by pressing the correct navigation element represented by pictogram by a finger.

To the each participant there was defined an objective to find concrete horticulture activity and display correct material. The timer was started after setting of an objective and it was stopped after the participant displayed the required material. The measured time of each participant is presented in table 2.

Values are rounded to whole seconds using a mathematical rounding. For the final evaluation there were selected only those participants who attended all the measurements and the health status allowed them to independent browsing of presented web interfaces. Only the results of five participants were included in the overall assessment at the end. During the measurement, there were only two wrongly or incorrectly displayed materials. These measurements were not included in the results and participants were able to start again.

During the observation of the each participant it was found that with a purely textual navigation most of them read the whole navigation first and then returning back to the required item by re-reading the entire navigation from left to the right. Noticeable are the differences between horizontal and vertical arrangement of the navigation. The vertical arrangement of individual items caused slower reading and worse overall orientation in navigation.

When using image navigation represented only by pictograms there was groping whether the pictogram truly represents the desired horticultural operation. By combining this type

\begin{tabular}{|c|c|c|c|c|}
\hline & $\begin{array}{c}\text { Text horizontal } \\
\text { navigation }\end{array}$ & $\begin{array}{c}\text { Text vertical } \\
\text { navigation }\end{array}$ & $\begin{array}{c}\text { Picture navigation } \\
\text { using applied } \\
\text { pictograms }\end{array}$ & $\begin{array}{l}\text { Picture navigation } \\
\text { using applied } \\
\text { pictograms } \\
\text { and short textual } \\
\text { description }\end{array}$ \\
\hline participant A & 12 & 15 & 12 & 7 \\
\hline participant B & - & - & - & - \\
\hline participant $\mathrm{C}$ & 10 & 12 & 9 & 5 \\
\hline participant D & 8 & 11 & 8 & 4 \\
\hline participant $E$ & 6 & 6 & 4 & 3 \\
\hline participant $F$ & - & - & - & - \\
\hline participant G & 9 & 11 & 7 & 3 \\
\hline participant $\mathbf{H}$ & - & - & - & - \\
\hline Arithmetic mean & 9 & 11 & 7 & 4 \\
\hline Median & 9 & 11 & 8 & 4 \\
\hline
\end{tabular}

Source: authors' own research

Table 2: Measured values of time needed to reach the objective in whole seconds. 


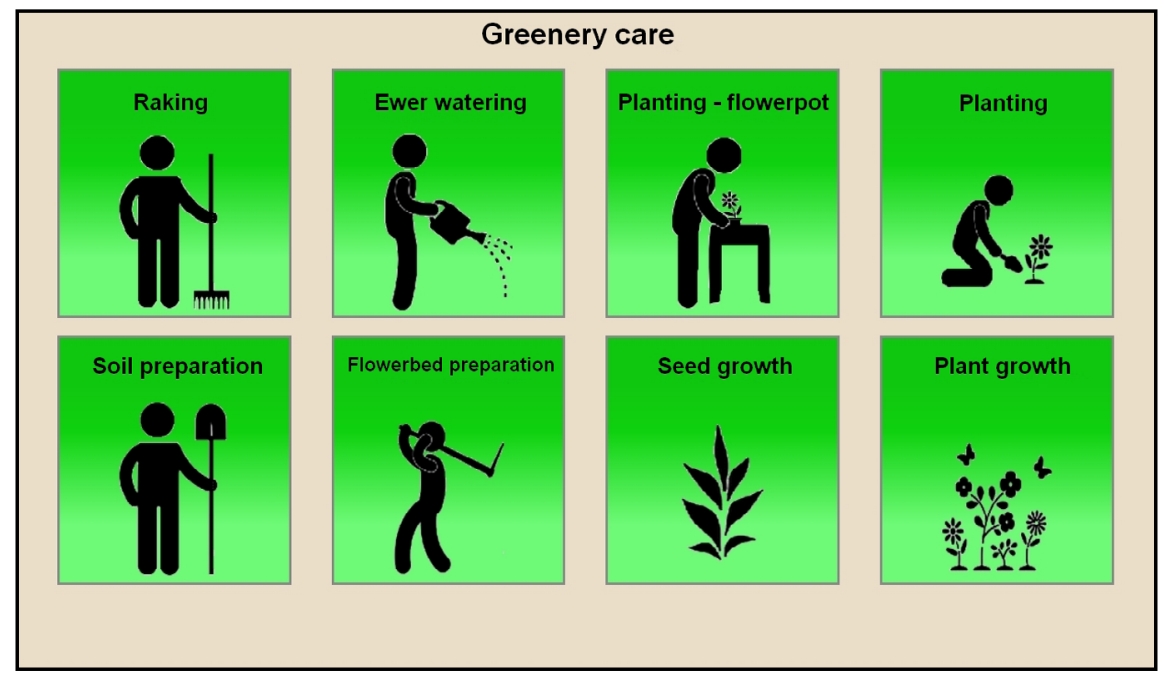

Source: authors' own research

Figure 1: final form of the web interface of the model course.

of navigation with text description all participants demonstrated the best results. Correct orientation in the web navigation consisted of the finding of learned pictogram and verifying the correctness also in a text label. In this case all participants pressed correct navigation pictogram without hesitation. All participants correctly identified pictogram as a navigation item and pressed it.

Performed observations and measured values show that the most appropriate form of web interface in the form of navigation is the use of pictograms with the text label (Figure 1).

\section{Conclusion}

The performed research shows that for the correct development of a web interface, there must be several factors considered. The first is the education of mentally disabled persons, which is based on a continuous exchange of information highlighted by pictograms. The second is the suitable form of control the web navigation by proper device. According to the conducted research and in comparison with scientific publications can mentioned the touch screen as the most suitable technology for controlling the web page. An effective control of devices by participants reached especially if the device was placed on solid surface and they have not to hold it with the other hand, zoom or scroll the content, or use the multi-touch. Because of the simple operation and control, the web page must adapt its content to the width of used device. For this reason it is also necessary to apply principles of responsive design during the creation of the web page. After the application of mentioned factors, performed observations and measured values presented that the most appropriate form of web interface for persons with mental disabilities is the use of simple pictograms with the text label.

\section{Aknowledgements}

The knowledge and data presented in the present paper were obtained as a result of the Grant No. 20151007 of the CULS Prague Internal Grant Agency titled „Innovative approaches to the use of ICT in education for mitigation of social exclusion" and the Grant No. 20151039 of the FEM CULS Prague Internal Grant Agency titled „Utilization of open data in the agrarian sector".

\section{Corresponding author:}

Ing. Petr Benda, Ph.D.

Department of Information Technologies, Faculty of Economics and Management, Czech University of Life Sciences Prague, Kamýcká 129, Praha 6-Suchdol, 16521, Czech Republic E-mail: bendap@pef.czu.cz 


\section{References}

[1] Bartoňová, M. et al. Integrace handicapovaných na trhu práce v mezinárodní dimenzi. Brno: MSD. 2005, 201 p. ISBN 80-866633-31-4.

[2] Benda, P., Havliček, Z., Lohr, V., Havránek, M. ICT helps to overcome disabilities. AGRIS on-line Papers in Economics and Informatics. 2011, Vol. III, No. 4, p. 63-70. ISSN: 1804-1930.

[3] Černá, M. Česká psychopedie. Speciální pedagogika osob s mentálním postižením. Prague: Karolinum. 2009, 222 p. ISBN 978-80-246-1565-3.

[4] Denaes, C. Analogical Matrices in Young Children and Students with Intellectual Disability: Reasoning by Analogy or Reasoning by Association?. Journal of applied research in intellectual disabilities: JARID. 2012, No. 25. ISSN 1360-2322.

[5] Huguenin, N. Reducing overselective attention to compound visual cues with extended training in adolescents with severe mental retardation. Research in developmental disabilities. 2000, No. 21, p. 93-113. ISSN 0891-4222.

[6] Kantor, J. Tvorba a realizace kurzů zaměřených na práci s žáky se speciálními vzdělávacími potřebami pro pedagogické pracovníky středních škol a druhého stupně základních škol. Olomouc: Pedagogical Faculty UP in Olomouc. 2012, p. 16-36. ISBN 978-80-244-3105-5.

[7] Keblová, M. Kompenzační pomůcky pro zrakově postižené žáky ZŠ. Prague: Septima, 2006. 60 p. ISBN 80-7216-104-0.

[8] Lestari, D. M., Hardianto, D., Hidayanto, A. N. Analysis of user experience quality on responsive web design from its informative perspective. Interntional Journal of Software Engineering and its Applications. Science and Engineering Research Support Society, 2014, Vol. 8, No. 5, 2014, p. 53 - 62. ISSN 1738-9984.

[9] Marcotte, E. Responsive Web Design. New Yourk: A Book Apart, 2011, 157 p. ISBN 978-0-9844425-7-7.

[10] Mesiti, M., Ribaudo, S., Valtolina, S., Barricelli, B. R., Boccacci, P., Dini, S. Collaborative Environments: Accessibility and Usability for Users with Special Needs. In Community-Built Databases. Heidelberg: Springer Berlin. 2011, p. 319-340. ISBN 978-3-642-19047-6.

[11] Pipeková, J. Pracovní uplatnění osob s mentálním postižením. Brno: Paido, 2010. p. 311-316. ISBN 978-80-7315-198-0.

[12] Stočes, P., Vaněk, J., Masner, J., Jarolímek, J. Mobile application development options for news and information portal. In Future Communication, Information and Computer Science proceedings. CRC Press, Leiden, 2015. p. 111 - 114. ISBN 9781138026537.

[13] Špinar, D. Tvoříme př́stupné webové stránky. Brno: Zoner Press, 2004, 360 p. ISBN 80-86815-11-0.

[14] StatCounter. World wide platform Comparison - Dec. 2014 [Online] Avalaible: $<$ http://gs.statcounter.com/\#desktop+mobile+tablet-comparison-ww-monthly-201412201412-bar/> [Accessed: 29 Jan. 2015]

[15] Švarcová, I. Mentální retardace: vzdělávání, výchova, sociální péče. Prague: Portál, 2006, 198 p. ISBN 80-736-7060-7.

[16] Tas, A., Tatnall, A. Use of ICT to Assist Students with Learning Difficulties: An Actor-Network Analysis. In Key Competencies in the Knowledge Society. In IFIP Advances in Information and Communication Technology. Boston: Springer Boston, 2010, p. 1-11. ISBN 978-3-642-15377-8.

[17] Valenta, M., Müller, O. Psychopedie. Prague: Parta, 2003. ISBN 80-7320-039-2.

[18] Van de Ven, J. A., de Haan. 2003. Mouse or touch screen. Computers in psychology. 2003, No. 7 , p. 191-204. ISSN 0925-9244. 